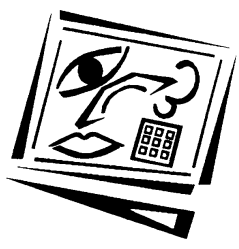

\title{
Bringing academics on board: Encouraging institution- wide diffusion of e-learning environments
}

\author{
Dawn Birch \\ University of Southern Queensland \\ Bruce Burnett \\ Queensland University of Technology
}

\begin{abstract}
Rapid advances in educational and information communications technology (ICT) have encouraged some educators to move beyond traditional face to face and distance education correspondence modes toward a rich, technology mediated e-learning environment. Ready access to multimedia at the desktop has provided the opportunity for educators to develop flexible, engaging and interactive learning resources incorporating multimedia and hypermedia. However, despite this opportunity, the adoption and integration of educational technologies by academics across the tertiary sector has typically been slow. This paper presents the findings of a qualitative study that investigated factors influencing the manner in which academics adopt and integrate educational technology and ICT. The research was conducted at a regional Australian university, the University of Southern Queensland (USQ), and focused on the development of e-learning environments. These e-learning environments include a range of multimodal learning objects and multiple representations of content that seek to cater for different learning styles and modal preferences, increase interaction, improve learning outcomes, provide a more inclusive and equitable curriculum and more closely mirror the on campus learning experience. This focus of this paper is primarily on the barriers or inhibitors academics reported in the study, including institutional barriers, individual inhibitors and pedagogical concerns. Strategies for addressing these obstacles are presented and implications and recommendations for educational institutions are discussed.
\end{abstract}

\section{Introduction}

This paper reports on the findings of a study that analysed institutional, individual and pedagogical factors influencing how academics develop e-learning environments for distance education students. The e-learning environments considered within the context of this study involve the development of engaging and interactive learning objects and elements that rely heavily on multiple presentation modes to represent the content knowledge and thus appeal to different learning styles and modal preferences (Birch \& Sankey, 2008). The study upon which this paper is based was conducted within a major distance education and e-learning provider in Australia, the University of Southern Queensland (USQ), where in 2003, academics commenced the process of converting traditional print based distance study materials into e-learning formats. This paper commences with a brief discussion of the cultural, technological and competitive market forces that have forced the distance education sector to evolve. This is followed by an explanation of the institutional context of the study along with a description of how e-learning environments targeting off campus students have been 
developed within this context. In the second half of the paper, literature unpacking institutional barriers, individual inhibitors and pedagogical concerns that impede the adoption and integration of educational technology is reviewed and the findings of the case study presented. The final section of the paper outlines implications and subsequent recommendations for distance education institutions and individual educators.

\section{The global transformation of distance education}

Advances in educational technologies have placed enormous pressure on the distance education sector to move beyond traditional correspondence modes and embrace an expanding e-learning environment. It has been suggested by Bates (2006) that without change the sector will not remain viable, particularly within the context of an increasingly competitive global distance education market. Indeed, Jochems, van Merrienboer and Koper (2004) propose that technological change has been so extensive that traditional approaches to distance education are no longer adequate and fail to meet the needs of new distance learners. Compounding market derived pressure to evolve is the simple reality that the majority of educators within developed nations now have extensive opportunities to develop interactive and engaging e-learning resources as a result of desktop access to multimedia and the Internet, combined with access to a range of new social networking platforms incorporated under the broad banner of Web 2.0.

While much pressure to change the way distance education is delivered can be traced to advances in technology, it is important not to overlook fundamental adjustments in the demographic profile of distance education student cohorts. The vast majority of contemporary distance education students appear to now study part time while working full time and this has clearly led to increased demands by this cohort of students for greater flexibility and mobility within their courses (Jafari, McGee \& Carmean 2006). Analysis of the distance education sector reveals the major extent to which the sector is currently grappling with unprecedented technological change, major social and demographic adjustments and, for the first time in its short history, extraordinary levels of market scrutiny due to the fact that the sector now operates within a truly global market.

\section{Institutional context for the research}

This paper reports the findings of a qualitative study which investigated both driving and restraining forces that influence academics' development of e-learning environments targeting distance education students at USQ. USQ is a major global provider of distance education and e-learning courses and has established an international reputation for excellence in the use of educational technology and the delivery of online education. Yearly enrolments exceed 26,000 students from over 120 nationalities with approximately $20 \%$ of enrolments being international or nonAustralian residents. In the order of $70 \%$ of the university's students study in distance education mode as either an external or web student. Importantly within the context of this paper, was the decision by university management, in 2003, to convert existing print based distance education materials to technology mediated e-learning formats (CD plus online) and, in the process, hopefully provide a more inclusive and equitable curriculum for distance students, more in line with the on campus experience, while reducing the considerable costs of printing and distributing print based packages. 
With the exception of some postgraduate courses that are delivered fully online, technology mediated e-learning environments at USQ typically comprise a printed introductory book and an interactive CD and are supplemented, to varying degrees, by an online course homepage. The interactive CD houses most of the course resources and includes introductory information, study modules, assessment items, readings and other useful resources. Multimedia enhancements may include video and audio content, recorded lecture presentations, video and graphics. However, academics have also been encouraged to develop interactive elements that provide multiple representations of important content to aid learning and appeal to kinaesthetic learners including interactive, audio enhanced diagrams and simulations, interactive quizzes and crosswords. Technology mediated delivery also allows the embedding of links to useful websites and hyperlinked examples and activities, including links to the course textbook website, educational websites, generic university resources and online course homepages. In more recent times (since 2006), a number of academics have implemented online video conferencing tools such as Elluminate and Wimba to provide a virtual classroom experience.

Despite the opportunity to provide distance education students with an interactive, enriched, more inclusive, equitable, flexible and convenient e-learning environment, by the end of 2007, less than ten percent of the approximately 1000 courses on offer had been converted to a technology mediated e-learning format. Thus, a major motivational component of this study was a desire to address this extremely slow diffusion rate and attempt to identify, more precisely, institutional barriers, individual inhibitors and pedagogical concerns that influence academics' development of elearning environments for distance education students.

\section{Details of the research project}

An exploratory case study was used to investigate factors that influence academics' adoption and integration of educational technology within e-learning environments at USQ (Yin, 2003). The primary source of data was gathered from in depth, semistructured interviews in which fourteen academics (four pioneers, six early adopters and four non-adopters) and three instructional designers were interviewed for the study between March and May in 2006. The academics came from various disciplines across three different faculties. Academics were asked about their use of, and attitudes toward, educational technology and what they perceived to be the motivations, enablers and inhibitors associated with the development of e-learning environments. Pioneers and adopters of the interactive, multimodal e-learning approach were asked to discuss their motivations, obstacles and experiences, while non-adopters were asked about barriers, inhibitors and pedagogical concerns and the possibility of developing an e-learning course in the future. The instructional designers were asked to provide insights into the pedagogical and individual motivations of these academics as well as some of the institutional factors that have enabled or inhibited academics in the conversion of print based distance education courses to e-learning formats. Interviewees were also asked about what direction the university should take with respect to the development of e-learning environments in the future.

Analysis of the interview data involved identifying key factors and related issues, and was driven by the key factors within the research framework, as presented in Figure 1 (namely pedagogical, individual and institutional factors, lessons learnt, and future directions). The responses from the interviews were examined for these key factors 
and related issues. Analysis of the interviews transcripts was conducted with the assistance of NVivo 7 software, which allowed the researcher to identify key themes and issues from the interview data. Themes and issues were subsequently clustered into three major areas representing institutional enablers and barriers, individual motivators and inhibitors, and pedagogical motivations and concerns.

\section{Framework of the research}

Based on an initial review of the literature, a framework for investigating the factors that influence academics' adoption and integration of educational technology within elearning environments for distance education students was developed and is presented in Figure 1 below.

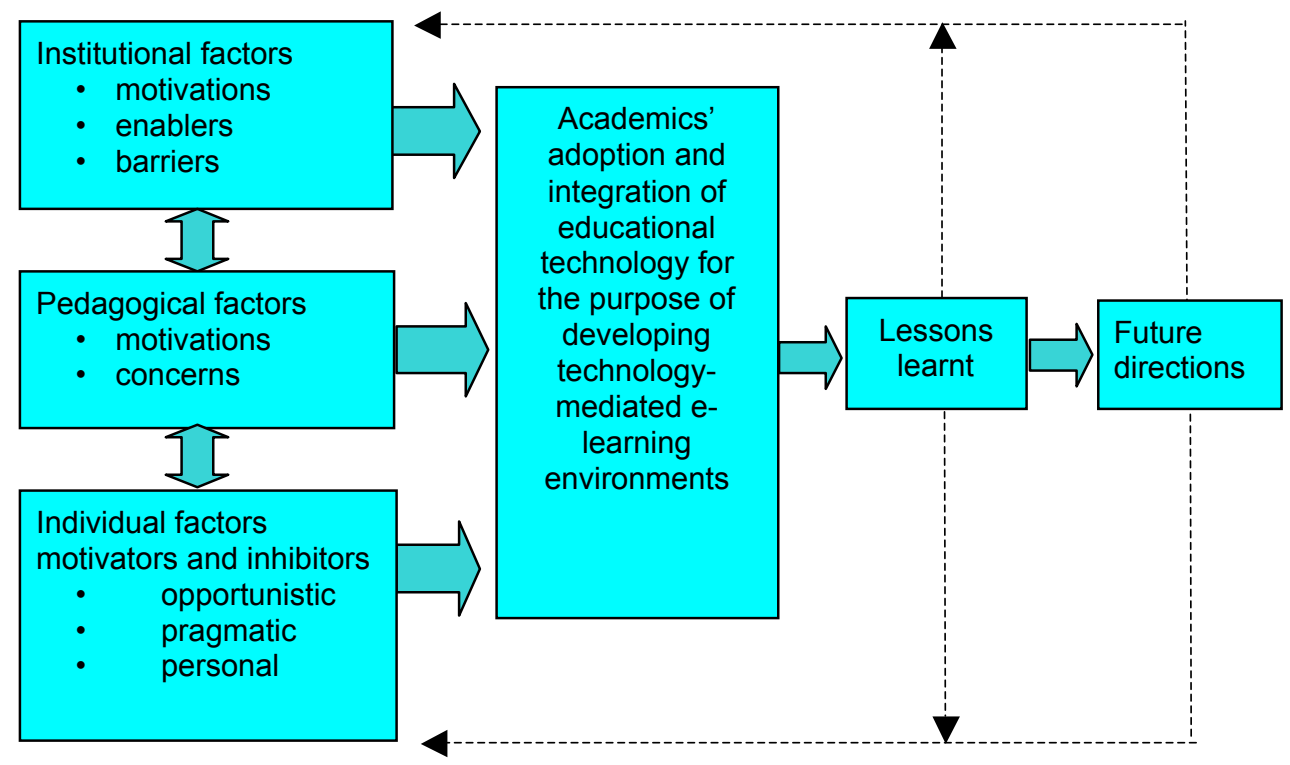

Figure 1: Factors influencing academics' development of e-learning environments

This framework indicates that it is predominately institutional, individual and pedagogical factors that impact on academics' adoption and integration of educational technology within e-learning environments. Institutional factors - including institutional motivations, enablers and barriers - are deemed to be within the jurisdiction and control of the institution. Conversely, individual factors relate to distinct academics and include opportunistic, pragmatic and personal motivators and inhibitors. Pedagogical factors on the other hand reflect both the educational goals of the institution as well as the pedagogical aims of individual academics. This framework allowed for the investigation of other factors that may influence the adoption and integration of educational technology that have not been identified in other contexts. Importantly, the framework indicated that past experience at both the individual and institutional level clearly impacts on the future direction e-learning takes. This paper focuses primarily on institutional barriers, individual inhibitors and pedagogical concerns. 


\section{Obstacles to academics' adoption and integration of educational technology}

The following section focuses on the literature concerning the obstacles (barriers, inhibitors, concerns) to academics' adoption and integration of educational technology. The discussion has been purposefully structured around the three distinct areas identified from the literature and captured in the research framework; namely, institutional, individual and pedagogical factors (Birch \& Sankey, 2008).

\section{Institutional barriers}

The literature revealed that major institutional barriers to academics' adoption and integration of educational technology include a lack of academic leadership, clear vision and formal strategic planning, and the absence of clear institutional policies, processes and standards (Maguire, 2005; McLean, 2005; Surry, Ensminger \& Haab, 2005). In particular, the lack of careful analysis of the curriculum to determine priorities and failure to develop and implement a technology plan based on clearly defined goals has created a barrier to effective diffusion and integration of educational technologies (Covington, Petherbridge \& Warren, 2005). A lack of institutional and administrative support including top management commitment also impedes the adoption and integration of educational technology (Benson \& Palaskas, 2006; Betts, 1998; Surry, Ensminger \& Haab, 2005). The literature stresses a lack of systems reliability, technological problems and malfunctions including slow download times and bandwidth issues are frustrating for both academics and students (Eastman \& Swift, 2001; Smith, 2001). The issue of inadequate infrastructure to support the technology and lack of access to appropriate or adequate hardware and software also impede technology adoption and integration (Capobianco \& Lehman, 2004; Jones \& Kelley, 2003; Surry, Ensminger \& Haab, 2005). The high cost of innovation and software coupled with limited resources has created a barrier to the adoption and integration of educational technology for both institutions and individual academics (Chizmar \& Williams, 2001; Ebersole \& Vorndam, 2003; Gulbahar, 2007).

Another frequently cited reason for the non-adoption and non-integration of educational technology is a lack of specialised and on going technical support (Bonk, 2001; Jones \& Moller, 2002; Lee, 2001; McCorkle, Alexander \& Reardon, 2001; Schifter, 2000). In particular, failure to provide specialised training in both use of the technology and understanding of how to effectively integrate the technology into the curriculum has impacted negatively on educational technology adoption and integration (Gulbahar, 2007; Mishra \& Koehler, 2006; Surry, Ensminger \& Haab, 2005). Jacobsen (1998) proposed that when adopting and integrating educational technology, "a different support infrastructure is clearly needed for mainstream faculty from that which sufficed for early adopters of technology" (p. 7). Hence, institutions should recognise the different needs of different adopter groups and tailor both support and training initiatives accordingly. The literature also revealed that the timing and source of the training to support technological initiatives must also be appropriate and relevant and specific to academics' needs and interests (Irani \& Telg, 2002: McLean, 2005). Further, a lack of mentors, role models and technology champions who are prepared to collaborate and share their experiences, conduct workshops and coach colleagues in the use of technology may inhibit the rapid diffusion of educational technology (Covington, et al., 2005; Wang, Ertmer \& Newby, 2004). 


\section{Individual inhibitors}

A major inhibitor to the adoption of educational technology revolves around perceived lack of time and the subsequent negative impact on academic workload (Schifter, 2000; Moser, 2007; O'Quinn \& Corry, 2002). The time required for developing technology skills, implementing technology and maintaining the courseware is a major area of concern for academics (Bonk, 2001; Cuban, Kirkpatrick \& Peck, 2001; Jones \& Kelley, 2003; Weston, 2005). Moreover, short life cycles, the need for constant updates, together with the development and maintenance of courses that involve educational technology compound an already time consuming activity (Brogden \& Couros, 2002; McCorkle et al., 2001; Weston, 2005). Betts (1998) in particular stresses the time it takes to adopt and effectively integrate educational technology impacts negatively on academics' workloads. This problem is exacerbated by tertiary institutions being reluctant or financially unable to offer release time to develop and update materials and allow course development activity within prescribed workloads (Chizmar \& Williams, 2001; Rockwell, Schauer, Fritz \& Marx, 1999; Weston, 2005). Given the time and resources it takes to successfully design and develop e-learning environments, a phased approach to implementation may lead to greater success (Carroll-Barefield, Smith, Prince \& Campbell, 2005). In particular, Kavanagh (2001) proposed that institutions with limited resources should start small, perhaps by relying in the early stages on the development of transferable, generic learning objects and then adding complexity over time (Daugherty \& Funke, 1998).

Adopting and integrating educational technology may leave academics with less time to devote to research and other activities that lead to promotion and tenure (Howell, Williams \& Lindsay, 2005; Maguire, 2005). Some academics also lack the personal motivation to explore the potential of e-learning in their teaching and have thus failed to embrace the opportunity to access technology as a means of enhancing their teaching and to be seen to be innovative, 'state of the art' and progressive (Betts, 1998; Cowan, 2006; Schifter, 2002). Conversely, the application of educational technology would appear to have appealed to other academics in terms of the excitement or novelty of doing something new, different or innovative (Smith, 2001; Wolcott \& Betts, 1999). Moreover, the adoption and integration of educational technology appears to have facilitated renewal and regeneration with some academics reporting a desire to 'energise' their teaching (Jones \& Kelley, 2003).

The literature proposes that later and non-adopters of educational technology may be less adventurous, more risk averse, less comfortable with change, less intrinsically motivated and less likely try new and novel ideas (Jacobsen, 1998; Rogers, 1995). Moreover, academics' attitudes toward technology in terms of their perceptions of its relative advantage over current methods, compatibility with current practices, usefulness and ease of use are primary determinants of whether a technology will be adopted (Davis, Bagozzi \& Warshaw, 1989; McPhail \& McDonald, 2004; Rogers, 1995). Resistance to change has not surprisingly been identified as major impediment to technology adoption and integration (McGee \& Diaz, 2007; Zhao \& Frank, 2003). Fear of change, a lack of willingness to take risks and lack of assurance about the benefits of technology have deterred some academics from adoption (Hunt, Eagle \& Kitchen, 2004; Weston, 2005). A lack of rewards and recognition has also been found to inhibit academics' willingness to adopt and integrate educational technology and participate in distance education (McCorkle, et al., 2001; Moser, 2007). 


\section{Pedagogical concerns}

While numerous and significant pedagogical benefits motivate academics to adopt and integrate educational technology, academics also express some concerns. Previous research has revealed a range of pedagogical motivations for the development of elearning environments including catering more effectively to the learning needs of different student groups and learning styles, improved learning outcomes, improved retention and progression rates, challenging students to become learner centred, self directed, resourceful and independent learners, replicating aspects of the on campus experience, engaging students in the learning experience, revitalising and reenergising the curriculum, and providing a richer learning environment (Birch \& Sankey 2008; Sankey \& St Hill 2005). However, despite these apparent pedagogical benefits, some academics express scepticism in terms of the benefits of educational technology for students while others identify potential negative impacts on learning (Ebersole \& Vorndam, 2003; McAlpine \& Gandell, 2003). The issues of limited working memory, split attention and cognitive overload that can arise from multiple representations of content (Jochems, et al., 2004; Sankey \& St Hill, 2005; Sweller, 1999) combined with the potential for the overuse of 'extras' (i.e., "bells and whistles") are argued to distract from the core content, leading to reduced learning (Moreno \& Mayer, 2007).

\section{Findings}

The next section provides findings from the study in relation to obstacles impeding academics' development of e-learning environments within the case university. The text commences with a discussion of institutional barriers followed by analysis of individual inhibitors and pedagogical concerns.

\section{Institutional barriers}

While interviewees acknowledged the excellent level of technological and instructional design support as well as access to advanced e-learning technologies provided at USQ, interviewees perceived that there was a lack of clear institutional direction concerning the design and delivery of distance education courses. In particular, interviewees expressed concerns regarding the apparent lack of program-wide strategic plans, clear policies, procedures and processes. Interviewees called for greater direction, ownership and accountability as well as the development and communication of a clear policy on the design and delivery of distance education materials. The majority of interviewees attributed the lack of widespread development of e-learning environments to a perceived lack of leadership.

One early adopter argued that "direction needs to come from the top." According to one instructional designer, the lack of clear policy statements with respect to the direction the university was taking in the design and delivery of course materials may have resulted in a situation whereby academics "sit back, and say 'well, no I won't really dive into the water and do this until I have to'." Indeed, three of the nonadopters indicated that in order for them to convert their print based courses to elearning format they would need to be directed by faculty management. The need for a clear, program-wide strategic plan for e-learning formats was identified with one of the early adopters commenting that "there's no coherent strategy to see a particular degree or program or anything converted. We're still out pioneering with people 
doing different things." A coherent, program-wide strategy was also deemed important by one of the non-adopters who argued that "a one size fits all approach" will not work, as what may work with one cohort of students may not work with another. This non-adopter also emphasised that a clear strategic plan would also allow the development of more effective staffing, workload and resource plans.

The lack of a clear process for development of e-learning environments was perceived to be a considerable obstacle for one early adopter who discussed the anxiety she had experienced due to her lack of knowledge and understanding of the process admitting that, "It was just like a complete mystery to me." Two of the pioneers also pointed out that "there's no induction into a process" rather "it's this vague thing out there that if you want to be part of it, just jump in the water and learn how to swim." One of these pioneers suggested the need for a set of clear guidelines, outlining the specific steps involved including who will be involved, who academics can talk to, who might serve as a mentor, how long the conversion from print to e-learning format will take, what needs to be done and direction on "which parts of your materials lend themselves to multimedia form."

Lack of tailored and specialised training for developing e-learning formats, particularly for academics who are "slow learners" and those who experience difficulty with new technology, was raised as another key barrier. The pioneers recommended a 'just in time' training approach at a time that suits academics and closer to when the knowledge can be used. One pioneer advised academics not to "do any training until you're actually ready to do it, because the training will change or the technology will change." One of the non-adopters explained that if he does not "have the time to play around with it" soon after the training, he quickly loses the knowledge he acquired. Finally, a perceived lack of mentors, role models and technology champions, as well as shared knowledge of possibilities and access to exemplars was considered to have created barriers to technology adoption.

The study also revealed a major barrier to adoption was concern regarding costs. An activity-based costing system which identified the costs of designing and delivering individual courses had deterred some academics from developing costly technologymediated resources and thus was perceived to have stifled innovation. Academics expressed concern about the commercial viability of their courses in a climate of cost cutting and rationalisation of programs and courses.

\section{Individual inhibitors}

Individual inhibitors to the development of e-learning formats included lack of time, increased academic workloads and perceived failure by the institution to provide time relief. Indeed, all of the pioneers perceived it had taken an "enormous amount of work" and "intense effort" to develop their e-learning environment, and one nonadopter expressed concern that it would require "a lot of effort and dedication." Interviewees revealed that time is required for thinking, conceptualising, researching, strategising, planning, learning about and coming to terms with the required technology, training, developing, editing, updating and maintenance. Early adopters and non-adopters expressed concerns about the lack of time to experiment, share experiences with colleagues, adapt their content and attend the requisite training. Moreover, an instructional designer explained that the development of multimedia elements within e-learning environments involves trial and error and "takes quite a bit of a mindset leap, and that needs time." One non-adopter for instance, explained that 
"before embarking upon what should be a revolutionised package, I'd need to know a lot, so that would take some time." In particular, less technologically-competent academics appear to require more time to learn how to use technology with one nonadopter stating, "I would need much more time than the average person to get up to speed to do those things." Critically, all of the pioneers commented on the time it takes to update and "ensure currency" of e-learning environments.

All those interviewed in the study perceived that the time taken to adopt and effectively integrate educational technology impacts negatively on academic workloads. With the exception of one pioneer, the other three pioneers in this study converted their courses 'above load' with one even using his long service leave to undertake the process. Interviewees agreed that unless workload is allocated for this purpose, wide scale development of e-learning environments may not eventuate. Given a lack of adequate workload allocation, one instructional designer argued that some academics will "make the call that it's easier to just do the print update." Interestingly, one early adopter observed, "the reality is that, maybe, the smarter ones than me won't do it until it's all made possible for them to do it." While one nonadopter advised that "time release" would motivate him to convert his course, other non-adopters confessed that it may be an issue of priorities, with one stating she was busy doing more "important things" and another admitting, "I've always got time for things that are important to me."

A staged approach to development whereby academics "gradually build up resources over time" was recommended by pioneers, early adopters and instructional designers. The most important elements such as those judged to "build in the greatest addition to the student's learning" could be developed for the first offering and then other elements can be added for subsequent offerings. According to one instructional designer, academics who are "willing to take a staged approach and not try to do everything at once," find the conversion from print to e-learning "quite manageable." In addition to taking a staged approach to development, is the need to aim for sustainable and scalable development with half of those interviewed advising against including information that was "time sensitive," thus reducing the need for "constant updating" which according to one of the pioneers was "an absolute nightmare!" It was suggested that elements should have "a shelf life of three or four years". Moreover, the value of developing re-usable learning objects, particularly when one is teaching both an undergraduate and a postgraduate course in a similar area was recommended. It was proposed that more costly and time consuming elements such as video "should stand the test of time," and one of the pioneers also issued a warning with respect to "the constantly changing nature" of external websites and thus the need to "limit examples to fairly stable external URLs."

Reduced time for undertaking discipline based research was identified by all interviewees as being a barrier to academics' development of e-learning environments. While one of the pioneers and two of the early adopters admitted their involvement had detracted from conducting discipline based research, others had taken the opportunity to conduct and publish research in the field of e-learning environments. This dichotomy surfaced throughout the study, as evidenced with some academics perceiving e-learning as an opportunity to explore new ways of designing and delivering distance education courses and being seen to be progressive or 'state of the art,' while others expressed concerns. Indeed, the interviews revealed that not all academics are interested in learning how to use educational technology and would 
prefer to leave the development of e-learning environments to others. Indeed some would prefer to "team teach and say to someone 'you do all the technology stuff, I'll do all the face to face and interaction'." Interestingly, instructional designers agreed that academics who "are intrinsically motivated to give the most for the students," have "a love of teaching," are "dedicated to the learning outcomes of their students" and "have always gone the extra mile with their students", appear to be more likely to develop e-learning environments. Conversely, the findings of this study indicated that academics who are less interested in teaching may be less likely to devote the time necessary to convert their print based materials to an e-learning format. Indeed, one of the pioneers explained that other academics who consider their teaching to be "more of an inconvenience to their research" may not have "that same predisposition towards taking it up."

In terms of an academic's personal characteristics, one instructional designer explained that many academics are "risk averse" and thus prefer to "wait for others to take the first step." She explained there are "people who face a new challenge, face a new idea quite willingly and quite positively," while "others draw back from that and don't want to do it until someone else has really proven that track." For example, one early adopter explained that while he does not perceive himself to be risk averse, he also does not "rush overboard into the first gimmick," rather he waits for the technology "to settle down just a little" before embracing it.

This study revealed that the adoption and integration of educational technology may depend upon technical capability and the existence of a set of required knowledge and skills. More importantly, negative attitudes toward change and technology, particularly understanding of how technology can be used to improve learning outcomes, appears to heavily influence academics' predisposition to develop or engage with e-learning. One early adopter, for example, suggested academics may be "hostile to it [technology] or are resistant to it because they don't see how it might improve what they're doing." Continuing the theme, one non-adopter advised against institutions simply "imposing new technologies on educators" and suggested the need to discuss with educators how the new technology could be used as well as implications for implementation.

In some cases, a perceived lack of rewards and lack of recognition from management and peers had inhibited academics' willingness to develop e-learning environments. For example, one early adopter perceived that "there's really no reward systems, no compensation for you doing it," while another observed, "from the Faculty point of view, it's well, that's what you're employed to do." One of the early adopters argued that if academics were encouraged and saw a "reward mechanism or something in it for themselves" then they would be more likely to get involved. Such sentiment is evident in the suggestion that possible rewards could include a "reduced marking load" or "some teaching relief." However, while the apparent lack of recognition and rewards from management and peers clearly inhibits later adopters' development of elearning environments, pioneers and early adopters stressed intrinsic rewards and recognition from students were the main motivational factors. One pioneer, for example, explained, "There are people out there who are placing a value on what I'm doing and they're the important ones, they're the students", while another considered that the best recognition he could receive was to know "that an increased number of students have found the course engaging." 


\section{Pedagogical concerns}

In this study, pedagogical motivations that influenced academics' development of elearning included the need to cater to the learning needs of different students including Generation Y, English second language (ESL) and students with a disability, the desire to improve student learning outcomes, retention and progression rates, and the need to challenge students to become learner centred, self directed, resourceful and independent learners. A key stimulus appears to be a desire to replicate the on campus experience, including facilitating multimodal learning, providing an equitable student learning experience, personalising the course and developing closer relationships with students, encouraging greater interactivity and providing more timely and individualised feedback. Pioneers and early adopters of e-learning valued the opportunity to revitalise the curriculum and reconceptualise their course. Other pedagogical motivations included the desire to engage students by making learning more enjoyable and providing a rich, current, relevant, meaningful and applicable learning environment.

Pedagogical concerns associated with the development of e-learning included the potential problems associated with cognitive overload and information overload. With 'overload' in mind, those interviewed stressed the need to carefully manage course content by rationalising and prioritising, providing manageable 'chunks' of information, and providing students with direction or 'procedural scaffolding' on how to effectively use the technology mediated e-learning resources in ways that matched their predominant learning style (McLoughlin, 2002). Three of the pioneers had, for example, removed textual content to ensure students were not "swamped," with one of these participants removing "about thirty percent of the content," which he deemed necessary to ensure "multiple representations" of content. One of the early adopters pointed out that when dealing with "time poor" adults, "we should not be wasting their valuable time" by asking them to do things that are not essential. Hence, he proposed that if you want to "add something useful, you may then have remove something, so it may require a trade off." One pioneer stressed the need to teach students "where to find the information, rather than give them all the information."

A clear lesson learnt by pioneers and early adopters was the need to provide students with direction on how to use technology mediated resources. Pioneers, for example, emphasised the need "to educate or prepare students on how to use the technology effectively", and explained that "you actually have to help them understand how they can use it, in order to improve their learning experience." The point was also made that in order to gain the greatest benefit from e-learning environments, students need to understand their own learning style and given the wealth of resources provided in e-learning environments, students need to self select those elements that will best assist them to learn. One pioneer explained that once students understand their learning modality they can use "the study materials to support that modality" and with this in mind, he encourages his students to access Fleming's (2001) VARK learning styles questionnaire online to determine their dominant learning style/(s) as early in the semester as possible.

Given the vast amount of information that can be housed in e-learning environments including multimedia elements and hyperlinks, pioneers perceived the need to point out to students what is important. Both early adopters and pioneers explained that most students are "risk averse" and thus believe they have to "go through everything," resulting in "information overload." It is important to provide students with 
information on how to approach e-learning materials. Due to language problems, another early adopter suggested that ESL students may need more direction, because they may not "recognise what is an important piece of information from a nonimportant piece of information." In order to provide this scaffolding, one pioneer had used a layered approach whereby information was identified as being "critical, recommended or suggested" to assist students to determine what was essential, desirable or optional.

\section{Discussion}

In line with the literature, interviewees perceived that there was a lack of clear institutional direction concerning the design and delivery of distance education courses, including a lack of clear strategic plans, policies, procedures and processes (Covington, et al., 2005; Maguire, 2005; McLean, 2005; Surry et al., 2005). In particular, the need for a clear, program wide strategic plan for e-learning formats was emphasised, so that students gained a consistent experience across their distance education program. Moreover, a program wide approach recognises that what may work with one cohort of students or in one program may not work with another. The study highlighted the need for tailored, specialised and timely training as well as ongoing one on one technical support, in particular for those less comfortable or familiar with the technology (Irani \& Telg, 2002: McLean, 2005). While the issue of the costs of educational technology has been frequently addressed in the literature, of particular interest in this study was the negative impact that the introduction of an activity based course costing system appeared to have on individual academics' motivations for the development of e-learning environments.

In support of previous studies, lack of time, increased academic workloads and absence of time relief were identified as major inhibitors to the development of elearning environments (Schifter, 2000; Moser, 2007; O'Quinn \& Corry, 2002). In this study, this issue of lack of time was unpacked to reveal that time is required from conceptualisation through to revision including time for thinking, researching, strategising, planning, learning about and coming to terms with the required technology, training, developing, editing, updating and maintenance. Interestingly, the in depth interviews revealed that it may be more a matter of priorities than time, with some academics revealing that they can find time for things that are important to themselves and their career and those which they perceived to be rewarded such as research. While reduced time for undertaking research is stated to be a major deterrent to the adoption of educational technology in the literature (Howell, Williams \& Lindsay, 2005; Maguire, 2005), many of the interviewees in this study had taken the opportunity to research and publish in the field of educational technology.

While the literature proposes that adoption and integration of educational technology is associated with particular personal characteristics and various adopter categories (Jacobsen, 1998; Rogers, 1995), this study revealed that some pioneers and early adopters of e-learning environments did not fit the stereotype. Indeed a number of the pioneers and early adopters considered themselves to be 'risk averse' regarding technology and to have limited technology capability, and yet they were still willing to adopt the technology if they perceived benefits for their students. A lack of rewards and recognition by management has been identified in numerous studies as a barrier to the adoption and integration of educational technology (McCorkle, et al., 2001; Moser, 2007). However, this study revealed that while extrinsic rewards such as teaching relief may be necessary to get non-adopters on board, pioneers and early 
adopters of e-learning environments were primarily motivated by intrinsic rather than extrinsic rewards, and student rather than management recognition.

Given the amount of available information and content that can be provided in an elearning environment and that e-learning represents a new way of learning for some students, the findings of this study clearly indicate the need to manage the content provided in an e-learning course and provide students with direction on how to use elearning resources effectively. In line with previous studies concerning providing multiple representations of content and e-learning approaches, the need to reduce cognitive overload and information overload were highlighted (Jochems et al., 2004; Sankey \& St Hill, 2005; Sweller, 1999). In particular, the need to rationalise and prioritise content, provide manageable 'chunks' of information, and 'procedural scaffolding' were emphasised (McLoughlin, 2002).

\section{Implications and recommendations}

In this section, a discussion of how the research undertaken in this study can impact practice is addressed. While this study has focussed on the shift from print based to elearning formats for distance education students at USQ, the findings are equally relevant for tertiary institutions making the shift from traditional face to face to blended/hybrid learning. A series of implications and subsequent recommendations for both educational institutions and individual academics are presented.

Major recommendations related to overcoming or mitigating institutional barriers to the development of e-learning environments include:

- development of a clear institutional direction, vision and policies concerning the design and delivery of e-learning environments;

- clear, strategic, program wide planning, procedures and processes;

- ongoing institutional and technical support;

- timely, specialised and tailored training as well as 'hands on' one to one support;

- access to instructional design and pedagogical advice for the integration of educational technologies; and

- the presence of mentors, role models and 'technology champions' as well as access to exemplars.

Implications and subsequent recommendations related to individual inhibitors revealed that educational institutions should encourage and support academics to develop e-learning environments to more closely match the requirements of today's students. However, given the time it takes to develop, maintain and update an elearning environment, recommendations to encourage wide scale development, as well as the realisation of the full potential of the use of multimedia and ICT, include:

- allocating workload or teaching relief;

- taking a sustainable approach by avoiding time-sensitive learning objects and developing re-usable learning objects; and

- taking a staged approach by developing the most valuable elements in terms of improving student learning outcomes first.

Educational institutions should encourage and support academics to develop elearning environments as a means of revitalising the curriculum and improving the quality of course content and delivery. To this end, educational institutions should: 
- encourage academics to research and publish on their learning and teaching strategies and use of educational technologies;

- support, value and reward research focussed on learning and teaching;

- take into consideration the time it takes academics to develop and maintain elearning environments in performance reviews and promotion interviews; and

- place greater value on effective teaching practice and the design and delivery of elearning environments in academic promotion rounds.

Widespread adoption of e-learning environments relies upon recognising, valuing and rewarding teaching. In particular, later adopters may be less intrinsically motivated and thus may need to be encouraged by extrinsic rewards such as a reduced marking load or teaching relief as well as formal recognition from management. Educational institutions also need to consider carefully the potential negative impacts of technological change and the way in which technologies are implemented on academics' willingness to embrace those technologies and integrate them into their teaching practice. Moreover, academics' preconceptions and traditional methodologies should be challenged and academics need to understand the nexus between technology, content and pedagogy.

Recommendations arising from implications related to pedagogical concerns regarding the development of e-learning environments include the need for academics to understand the importance of inclusive learning packages which appeal to different learning styles and modal preferences, with the aim of improving student learning outcomes. However, the potential for cognitive and information overload in e-learning environments means that there is the need to:

- rationalise and prioritise the course content;

- add value while avoiding cognitive and information overload; and

- provide procedural scaffolding for students on how to effectively use e-learning resources.

\section{Limitations and future research}

This paper has focused on a number of institutional barriers, individual inhibitors and pedagogical concerns factors that appear to impede academics' development of elearning environments. The research was confined to USQ, which while being a major provider, is one of many providers of distance education across the globe. Due to contextual issues, individual factors that influence academics' adoption and integration of educational technology and ICT for the purpose of developing elearning environments at USQ may differ from other distance education providers. Hence, other distance education providers who are developing or intend to develop elearning environments may need to conduct a similar study to determine if the factors that impact on academics at USQ differ from their institution. Indeed, given USQ's extensive experience and expertise in distance education, and more recently in elearning, other institutions with less experience in distance education may not have established the same level of expertise and infrastructure support and thus may face even greater challenges.

Conversely, tertiary institutions which are receiving higher levels of government funding than USQ may not be experiencing the same resource constraints and thus may be in the position to provide higher levels of specialised training and one on one 
support to academics. Finally, given that e-learning appears to be the way of the future, the issue of non-adoption of e-learning technologies by many academics needs further investigation.

Institutional barriers, individual inhibitors and pedagogical concerns impede academics' adoption and integration of educational technology and thus may account for slow diffusion. Given the numerous benefits to be gained for the institution, individual academics and students associated with the development of e-learning environments, educational institutions need to seek to overcome barriers and encourage, support and reward academics to convert static, print based distance education courses and/or traditional face to face courses to an e-learning format in order to cater for the needs of different students and develop a more inclusive, equitable, engaging, flexible and convenient learning environment that will lead to improved learning outcomes.

\section{References}

Bates, T. (2006). Technology, e-Learning and distance education. New York: Abingdon.

Benson, R. \& Palaskas, T. (2006). Introducing a new management learning system: An institutional case study. Australasian Journal of Educational Technology, 22(4), 548-567. http: / / www.ascilite.org.au/ajet/ajet22/benson.html

Betts, K. S. (1998). An institutional overview: Factors influencing faculty participation in distance education in the United States: An institutional study. Online Journal of Distance Learning Administration, 1(3). [verified 12 Feb 2009] http:/ / www.westga.edu/ distance/betts13.html

Birch, D. \& Sankey, M. (2008). Drivers for and obstacles to academics' development of interactive multimodal technology-mediated distance education courses. International Journal of Education and Development using ICT, 4(1). [verified 12 Feb 2009] http: / / ijedict.dec.uwi.edu / viewarticle.php?id=375\&layout=html

Bonk, C. J. (2001). Online teaching in an online world. Bloomington: CourseShare.com. [viewed 10 May 2005, verified 12 Feb 2009] http:/ / publicationshare.com/docs/ faculty_survey_report.pdf

Brogden, L. \& Couros, A. (2002). Contemplating the virtual campus: Pedagogical and administrative considerations. The Delta Kappa Gamma Bulletin, 68(3), 22-30.

Carroll-Barefield, A., Smith, S. P., Prince, L. H. \& Campbell, C. A. (2005). Transitioning from brick and mortar to online: A faculty perspective. Online Journal of Distance Learning Administration, 8(1). [verified 12 Feb 2009]

http: / / www.westga.edu / distance/ ojdla/ spring81/ carroll81.htm

Capobianco, B. \& Lehman, J. (2004). Using technology to promote inquiry in elementary science teacher education: A case study of one teacher educator's initiatives. Society for Information Technology and Teacher Education International Conference 2004, (1), 4625-4630.

Chizmar, J. F. \& Williams, D. B. (2001). What do faculty want? EDUCAUSE Quarterly, 1, 18-24. [verified 12 Feb 2009] http: / / net.educause.edu/ir/library/pdf/eqm0112.pdf

Covington, D., Petherbridge, D. \& Warren, S. E. (2005). Best practices: A triangulated support approach in transitioning academic to online teaching. Online Journal of Distance Learning Administration, 8(1). [verified 12 Feb 2009]

http:/ / www.westga.edu/ distance/ ojdla/spring81/ covington81.htm

Cowan, J. (2006). On becoming an innovative university teacher. New York: Open University Press. 
Cuban, L., Kirkpatrick, H. \& Peck, C. (2001). High access and low use of technologies in high school classrooms: Explaining an apparent paradox. American Educational Research Journal, 38(4), 813-834.

Daugherty, M. \& Funke, B. L. (1998). University faculty and student perceptions of web-based instruction. Journal of Distance Education, 13(1), 21-39.

Davis, F. D., Bagozzi, R. P. \& Warshaw, P. R. (1989). User acceptance of computer technology: A comparison of two theoretical models. Management Science, 35(8), 982-1003.

Eastman, J. K. \& Swift, C. O. (2001). New horizons in distance education: The online learnercentered marketing class. Journal of Marketing Education, 23(1), 25-34.

Ebersole, S. \& Vorndam, M. (2003). Adoption of computer-based instructional methodologies: A case study. International Journal on E-Learning, 2(2), 15-20.

Fleming, N. (2001). VARK: A guide to learning styles. [viewed 30 Nov 2004, verified 12 Feb 2009] http:/ / www.vark-learn.com/english/page.asp?p=questionnaire

Gulbahar, Y. (2007). Technology planning: A roadmap for successful technology integration in schools. Computers \& Education, 49, 943-956.

Howell, S. L., Williams, P. B. \& Lindsay, N. K. (2005). Thirty-two trends affecting distance education: An informed foundation for strategic planning. Online Journal of Distance Learning Administration, 6(3). [verified 12 Feb 2009] http:/ / www.westga.edu/ distance/ojdla/ fall63/howell63.html

Hunt, L., Eagle, L. \& Kitchen, P. J. (2004). Balancing marketing education and information technology: Matching needs or needing a better match. Journal of Marketing Education, 26(1), 75-88.

Irani, T. \& Telg, R. (2002). Building it so they will come: Assessing universities' distance education faculty training and development programs. Journal of Distance Education, 17(1), 3646.

Jacobsen, D. M. (1998). Adoption patterns of faculty who integrate computer technology for teaching and learning in higher education. Proceedings of the Ed-Media and Ed-Telecom 98: World Conference on Educational Multimedia and Hypermedia $\mathcal{E}$ World Conference on Educational Telecommunications, Freiburg, Germany, June 20-25.

Jafari, A., McGee, P. \& Carmean, C. (2006). Managing courses, defining learning: What faculty, students, and administrators want. EDUCAUSE, July-August 2006, 50-70. http: / / net.educause.edu/ir/library/pdf/ERM0643.pdf

Jochems, W., van Merrienboer, J. \& Koper, R. (2004). Integrated e-learning: Implications for pedagogy, technology and organisation. London: Routledge Falmer.

Jones, A. \& Moller, L. (2002). A comparison of continuing education and resident faculty attitudes towards distance education in a higher education institution in Pennsylvania. College and University Media Review, 9(1), 11-37.

Jones, K. O. \& Kelley, C. A. (2003). Teaching marketing via the Web: Lessons learned and challenges to be met. Marketing Education Review, 13(1), 81-89.

Kavanagh, M. (2001). Managing change to flexible learning using online technologies: Bridges to cross, lessons to learn. Proceedings of Society for Information Technology and Teacher Education International Conference 2001, (511-516). 
Lee, J. (2001). Instructional support for distance education and faculty motivation, commitment, satisfaction. British Journal of Educational Technology, 32(2), 153-160.

Maguire, L. L. (2005). Literature review: Faculty participation in online distance education: Barriers and motivators. Online Journal of Distance Learning Administration, 8(1). [verified 12 Feb 2009] http: / / www.westga.edu/ distance/ojdla/spring81/maguire81.htm

McAlpine, L. \& Gandell, T. (2003). Teaching improvement grants: What they tell us about professors' instructional choices for the use of technology in higher education. British Journal of Educational Technology, 34(3), 281-293.

McCorkle, D. E., Alexander, J. F. \& Reardon, J. (2001). Integrating business technology and marketing education: Enhancing the diffusion process through technology champions. Journal of Marketing Education, 23(1), 16-24.

McGee, P. \& Diaz, V. (2007). Wikis and podcasts and blogs! Oh, my! What is a faculty member supposed to do? EDUCAUSE, September-October, 2007, 28-40. [verified 12 Feb 2009] http:/ / net.educause.edu/ir/library/pdf/ERM0751.pdf

McLean, J. (2005). Addressing faculty concerns about distance learning. Online Journal of Distance Learning Administration, 8(4). [verified 12 Feb 2009] http:/ / www.westga.edu / distance/ ojdla/winter84/ mclean84.htm

McLoughlin, C. (2002). Learner support in distance and networked learning environments: Ten dimensions for successful design. Distance Education, 23(2), 149-162.

McPhail, J. \& McDonald, J. (2004). Predicting undergraduate students' acceptance and use of learning resources on CD-ROM: Test of an extended technology acceptance model. Proceedings of the Academy of World Business, Marketing and Management Development Conference, July 13-16, 2004, Gold Coast, Australia.

Mishra, P. \& Koehler, M. (2006). Technological pedagogical content knowledge: A framework for teacher knowledge. Teachers College Record, 108(6), 1017-1054.

Moreno, R. \& Mayer, R. (2007). Interactive multimodal learning environments. Educational Psychology Review, 19, 309-326.

Moser, F. Z. (2007). Faculty adoption of educational technology. EDUCAUSE Quarterly, 1, 66-69. [verified 12 Feb 2009] http:/ / net.educause.edu/ir/library/pdf/eqm07111.pdf

O'Quinn, L. \& Corry, M. (2002). Factors that deter faculty from participating in distance education. Online Journal of Distance Learning Administration, 5(4), 1-18. [verified 12 Feb 2009] http:/ / www.westga.edu/ distance/ojdla/winter54/Quinn54.htm

Rockwell, S. K., Schauer, J., Fritz, S. M. \& Marx, D. B. (1999). Incentives and obstacles influencing higher education faculty and administrators to teach via distance. Online Journal of Distance Learning Administration, 3(2). [verified 12 Feb 2009] http: / / www.westga.edu/ distance/ rockwell32.html

Rogers, E. M. (1995). Diffusion of innovations (4th ed.). New York: Free Press.

Sankey, M. \& St Hill, R. (2005). Multimodal design for hybrid learning materials in a second level economics course. Proceedings of 11th Australasian Teaching Economics Conference: Innovation for Student Engagement in Economics, July 11-12, 2005, University of Sydney, Australia (98-106). [verified 12 Feb 2009] http:/ / eprints.usq.edu.au/267/1/Sankey_StHill_05.pdf

Schifter, C. C. (2000). Faculty motivators and inhibitors for participation in distance education. Educational Technology, 40(2), 43-6. 
Schifter, C. C. (2002). Perception differences about participating in distance education. Online Journal of Distance Learning Administration, 5(1). [verified 12 Feb 2009] http:/ / www.westga.edu/ distance/ ojdla/spring51/schifter51.html

Smith, L. J. (2001). Content and delivery: A comparison and contrast of electronic and traditional MBA marketing planning courses. Journal of Marketing Education, 23(1), 35-44.

Surry, D. W., Ensminger, D. C. \& Haab, M. (2005). A model for integrating instructional technology into higher education. British Journal of Educational Technology, 36(2), 327-329.

Sweller, J. (1999). Instructional design in technical areas. Camberwell. Australia: ACER Press.

Wang, L., Ertmer, P. A. \& Newby, T. (2004). Increasing pre-service teachers' self-efficacy beliefs for technology integration. Journal of Research on Technology in Education, 36(3), 231-50.

Weston, T. J. (2005). Why faculty did - or did not - integrate instructional software in their undergraduate classrooms. Innovative Higher Education, 30(2), 99-115.

Wolcott, L. L. \& Betts, K. S. (1999). What's in it for me? Incentives for faculty participation in distance education. Journal of Distance Education, 14(2), 34-49.

Yin, R. K. (2003). Case study research: Design and methods (3rd ed.). Thousand Oaks: Sage.

Zhao, Y. \& Frank, K. A. (2003). Factors affecting technology uses in schools: An ecological perspective. American Educational Research Journal, 40, 807-841. [verified 12 Feb 2009] https: / / www.msu.edu/ kenfrank/ papers / Factors $\% 20$ affecting $\% 20$ technology $\% 20$ uses $\% 20$ in $\% 20$ schools.pdf

Dr Dawn Birch is a Senior Lecturer in the School of Management and Marketing at the University of Southern Queensland. Dawn has published in the areas of education, domestic barter, international advertising, services marketing and shopping centre management. Her current research focuses on academics' adoption and integration of educational technology for developing interactive, multi-modal e-learning environments.

Dr Dawn Birch, School of Management and Marketing, Faculty of Business, University of Southern Queensland, Toowoomba Qld 4350, Australia. Email: birch@usq.edu.au Web: http:/ / www.usq.edu.au/users/birch

Dr Bruce Burnett is a Senior Lecturer in the School of Cultural Language Studies in Education at the Queensland University of Technology. Bruce has background in Sociology of Education and in particular the areas of narrative analysis, the sociocultural impact of new technologies and Japanese education. His current research focuses both on the Australian and Japanese educational contexts.

Dr Bruce Burnett, School of Cultural Language Studies, Faculty of Education, Queensland University of Technology, Kelvin Grove Qld, Australia.

Email: b.burnett@qut.edu.au 